\title{
Scientific investigation by technical photography, OM, ESEM, XRF, XRD and FTIR of an ancient Egyptian polychrome wooden coffin
}

\author{
Ahmed Abdrabou* \\ Medhat Abdallah \\ Hussein M. Kamal \\ Wood laboratory, Grand Egyptian Museum - Conservation Centre, Ministry of Antiquities, Giza, Egypt \\ *ahmed_abdrabou87@yahoo.com
}

\begin{abstract}
The focus of this study is to use a multi-analytical approach to map and identify the pigments used on a polychrome wooden coffin (Late Period), as well as to provide a deeper understanding of the painting techniques and the condition of the object. Moreover, the authors are significantly interested in the identification of the wood species. These were identified by observing the thin sections of samples under an optical transmission light microscope; the painted materials layered on the wood surface were analyzed by several scientific and analytical methods. Furthermore, the previous consolidation material and salts were also identified. The application of technical photography provided useful information about the spatial distribution of the surviving original pigments and the materials used in previous restoration interventions, in particular visible-induced luminescence, which played an important role to recognize spatial distribution of areas containing Egyptian blue, even if it is in traces or mixed with other pigments. However complete characterization of the pigments was only possible with the use of other techniques.
\end{abstract}

Estudo científico de um antigo sarcófago egípcio de madeira policromada por fotografia técnica, OM, ESEM, XRF, XRD e FTIR

\section{Resumo}

Este estudo pretende usar uma abordagem multi-analítica para mapear e identificar os pigmentos usados num sarcófago de madeira policromada (Época Baixa), assim como proporcionar um mais detalhado conhecimento das técnicas de pintura e do seu estado de conservação. Além disso, os autores estão especialmente interessados na identificação das espécies de madeira. Estas foram identificadas através da observação, ao microscópio óptico de transmissão, de lâminas delgadas e a camada cromática sobre a madeira foi analisada com o recurso a diferentes métodos de exame e análise. Além disso foram igualmente identificados o material de consolidação utilizado numa intervenção anterior e os sais. A fotografia técnica proporcionou informação útil sobre a distribuição espacial dos pigmentos originais e dos materiais usados em anteriores intervenções. A luminescência visível induzida foi sobremaneira útil para se perceber a distribuição do azul egípcio, mesmo quando em concentrações vestigiais ou misturado com outros pigmentos. No entanto, a caracterização detalhada dos pigmentos só foi possível através dos outros métodos usados.

\section{Keywords}

Polychrome wooden coffin

Wood species

Technical photography

Egyptian blue

\section{Palavras-chave}

Sarcófago de madeira policromada Espécies de madeira Fotografia técnica

Azul egípcio 


\section{Introduction}

The identification of the components of ancient Egyptian polychrome coffins has received much interest in the last decades; for their study, various destructive and non-destructive analytical techniques have been applied by many authors. For example, in order to characterize and identify wood species, ground layer, paint layers, binding medium and previous restoration materials, to yield information useful for the conservation processes, the combined approach involving optical microscopy, scanning electron microscopy, X-ray diffraction and Fourier transform infrared spectroscopy was applied to polychrome wooden coffins by many authors [1-4]. A multi-analytical study including optical microscopy, scanning electron microscopy-energy dispersive spectroscopy, Raman and surface enhanced (resonance) Raman spectroscopy, infrared and GC-MS techniques was applied to characterize the composition of the painted layer on a decorated wooden sarcophagus [5]. The combination of image analyses and spot analysis without sampling, along with sample spot analysis, was applied to study the construction techniques and the painting materials, as well as the modern restoration intervention, in the Vatican Coffin project [6]. Further, a multidisciplinary approach combining imaging and spectroscopic techniques was applied for the study of an Egyptian coffin (late 22nd early 25th dynasty) [7].

In this study, we used a combination of optical microscopy and technical photography along with portable X-ray fluorescence, X-ray diffraction and Fourier transform infrared spectroscopy in order to map and identify the pigments used on a polychrome wooden coffin, as well as to provide a deeper understanding of the painting techniques and the condition of the object. Moreover, we were significantly interested in the identification of the wood species.

\section{Historical background}

The studied coffin was excavated from the Saqqara archaeological site by an Egyptian-Czech mission and registered under the number 2630 at the Saqqara storage. In 2015, it was transported to the Conservation Centre of the Grand Egyptian Museum (GEM-CC) under the GEM number 10831. This anthropoid coffin is dated as being from the late period (712-332 BC) and contains cartonnage fragments and a mummy inside it. It is constructed from several pieces of wood covered with painted preparation layers. The exterior surface of the coffin lid is decorated with broad collars, made of layers of a floral multicolored necklace. Under the necklace there is the representation of Nut, the goddess of the sky and of the vault of heaven, sitting on her right heel, facing left and stretching her wings and the sun disc on her head. The lower part of the coffin lid is decorated with three columns of hieroglyphic inscriptions. Two figures of god
Anubis on his shrine are depicted on the foot area. The underside of the coffin box is decorated with a protective goddess. Four rectangular mortises on each side of the top edge of the coffin box correspond to sites where wooden tenons (loose tongues) were slotted into place to secure the lid. Circular holes piercing the walls of the coffin box once held dowels that were used to lock these tenons when the lid was closed. The coffin dimensions are about $198 \mathrm{~cm}$ in length and $59.5 \mathrm{~cm}$ in width. The coffin was previously restored during excavation to secure and stabilize its painted layers, using gauze and Primal AC 33. This procedure caused discoloration, missing parts and flaking of the painted preparation layers in many places. In addition, sand deposits and fiber particles were extensively adhered to the surface of the pigments, which saturated and obscured some parts of painted surfaces. Moreover, salt efflorescence was observed in different parts of the coffin. This study was started in the Wood Conservation Laboratory of GEM-CC.

\section{Materials and methods}

\section{Sampling}

X-ray fluorescence spectrometry (XRF) analyses were performed directly on differently colored areas according to information on color differences coming from technical photography techniques (at least two points for each color). As the painted preparation layers of the coffin exhibited detachment and some flaking, some fallen samples representing the different painted preparation layers were carefully chosen for analysis. From portions of the fallen samples, cross-sections were prepared. It should be noted that the XRF measurements were also performed on the fallen samples. Also, two samples from the salt efflorescences and the previous consolidation material were carefully scraped off with a metallic scalpel for the analysis. In order to identify the wood species, the coffin were sampled at five points. Three samples were obtained from the wooden planks, while the fourth and fifth samples were obtained from an original wooden dowel and from the remains of an incomplete tenon.

Wood samples were cut into the three principal anatomical directions: transverse, tangential longitudinal and radial longitudinal. These three thin sections were then mounted on glasses to be observed under transmitted light using Optika Microscopy (Italy) equipped with an Optika B 9 Digital Camera. The observation and description of anatomical features allowed the identification of the taxon of the wood samples through comparison with the description available in wood anatomy textbooks, atlases and database [8-11].

\section{Optical and scanning electron microscopies}

Morphological and stratigraphic investigations were performed by using optical microscopy (OM) and scanning 
electron microscopy (SEM). OM images were taken with a Zeiss Stereo DV 20 microscope equipped with an Axio Cam MRC5. SEM images, by backscattered electrons (BSE), were taken with a Quanta 3D 200i scanning electron microscope made by FEI. Epoxy resin (Epofix, Struers) was used for the preparation of cross sections.

\section{Technical photography (TP)}

The technical images presented in this paper - visible (VIS), visible-induced ultraviolet luminescence (UVL), visible-induced infrared luminescence (VIL) and infrared (IR) - were acquired with a Nikon D90 DSLR (CMOS sensor) digital camera modified for "full spectrum" (between about 360 and $1100 \mathrm{~nm}$ ) and fitted with a Nikon Nikkor $60 \mathrm{~mm}$ f/1:2.8D AF lens. The camera was operated in fully manual mode and was tethered to a computer to allow sharp focusing in non-visible modes (IR and UV) using live view mode. The camera has been calibrated with the X-rite Color Checker Passport and its bundled software to create a camera profile for Adobe Camera Raw. The images were shot RAW and were then color corrected, using the camera profile, and white balanced [12-13]. For visible imaging the excitation was provided by two photographic white light fluorescent sources and the camera lens was fitted with B + W 486 band pass filter (c. 400-700 nm). For UIL imaging the excitation was provided by two UV radiation sources (365 $\mathrm{nm})$ and the camera lens was fitted with B + W 420 and $\mathrm{B}+\mathrm{W} 486$ band pass filter (c. 400-700 nm). For VIL imaging the excitation was provided by two white LED light sources and the camera lens was fitted with a Schott RG 840 cut-on filter. In the VIL images, Egyptian blue shows up as bright areas against a dark background [1415]. For infrared imaging the excitation was provided by two LED IR radiation sources $(900 \mathrm{~nm})$ and the camera lens was fitted with a Schott RG840 cut-on filter [16]. The infrared false color images are made by digitally editing the VIS and IR images. A copy of the VIS image is edited to become the IRFC image, with splitting into its red, green and blue (RGB) components. The green channel substitutes the blue channel and the red channel the green channel. Then, the IR image constitutes the red channel of the edited VIS [17].

\section{Portable X-ray fluorescence (XRF)}

The measurements were performed with a Niton XL3t Goldd handheld XRF spectrophotometer instrument using the Niton XL3t X-ray tube based analyzer with Ag anode, $50 \mathrm{kV}$ and $0-200 \mu \mathrm{A}$ max. The instrument head was placed in contact with the selected area and the irradiated area was about $4 \mathrm{~mm}$ radius. It is a completely portable instrument with a one-hand trigger operation, a touch screen with full navigation, and a complete energy spectra view. All points were exposed for a minimum of 50 seconds. XRF spectra were produced using Niton Data Transfer software.

\section{Fourier transform infrared spectroscopy (FTIR)}

Fourier transform infrared spectroscopy was done using an FTIR spectrometer (IRPrestige-21, Shimadzu) in the $400-4000 \mathrm{~cm}^{-1}$ range, with a resolution of $8 \mathrm{~cm}^{-1}$. A previous consolidation material sample and other samples of painted preparation layers were identified by comparing the obtained spectra with literature data [18] and standards created in the FTIR laboratory.

\section{X-ray diffraction (XRD)}

The fallen samples of the painted preparation layers were analyzed in a nondestructive mode without any sample preparation by X-ray diffraction using an X-ray diffractometer system PW3040 - Analytical Equipment PANalytical Pro model with a $\mathrm{Cu}$ anode, working at 30 $\mathrm{mA} / 40 \mathrm{kV}$ (an approximately flat surfaced sample was attached into the sample holder inside the XRD apparatus). X'Pert Highscore software was used for identifying the components of the painted preparation layers.

\section{Results and discussion}

\section{Identification of wood species}

The microphotographs of wood thin sections (Figures 1-3) showed that sycamore fig (ficus sycomorus) was used for making the coffin planks, while Nile acacia (acacia nilotica) was used for making the dowels, and Nile tamarisk (tamarix nilotica) for the tenons. The characteristic anatomical features of sycamore fig, Nile acacia and Nile tamarisk are presented in Table 1. Sycamore fig is recorded as being native to Egypt and was used extensively in ancient Egypt with other indigenous wood, such as acacia and tamarisk, for coffin construction [1, 2, 19]. Sycamore fig is one of the relatively few local trees that grow tall enough to yield the long lengths of timber suitable for coffin planks, besides having considerable religious significance, since it, and its fruits in particular, was associated with the goddess Nut. Although much used in ancient Egypt, sycamore fig wood is light, not of high quality and is prone to insect attack. However, the thick preparation layers and pigments that covered the coffin wood planks reduced these drawbacks [20]. Nile acacia is recorded as being native to Egypt, growing on the Nile banks, and is seldom straight growing, of great length or girth, although it is very hard, heavy and durable [21]. Such properties made it most suitable for use as dowels or pegs in connective carpentry in ancient Egypt. The species of tamarisk present in Egypt, the Sahara and adjacent regions are very similar in many anatomical features such as vessels groupings, parenchyma arrangement, and ray composition. The distinction between the species is normally based on some features such as vessels porosity, ray width, crystal and sheath cells. In this case, according to the anatomical features, shown in figure 3, we suggested that the wood used in the tenon is 

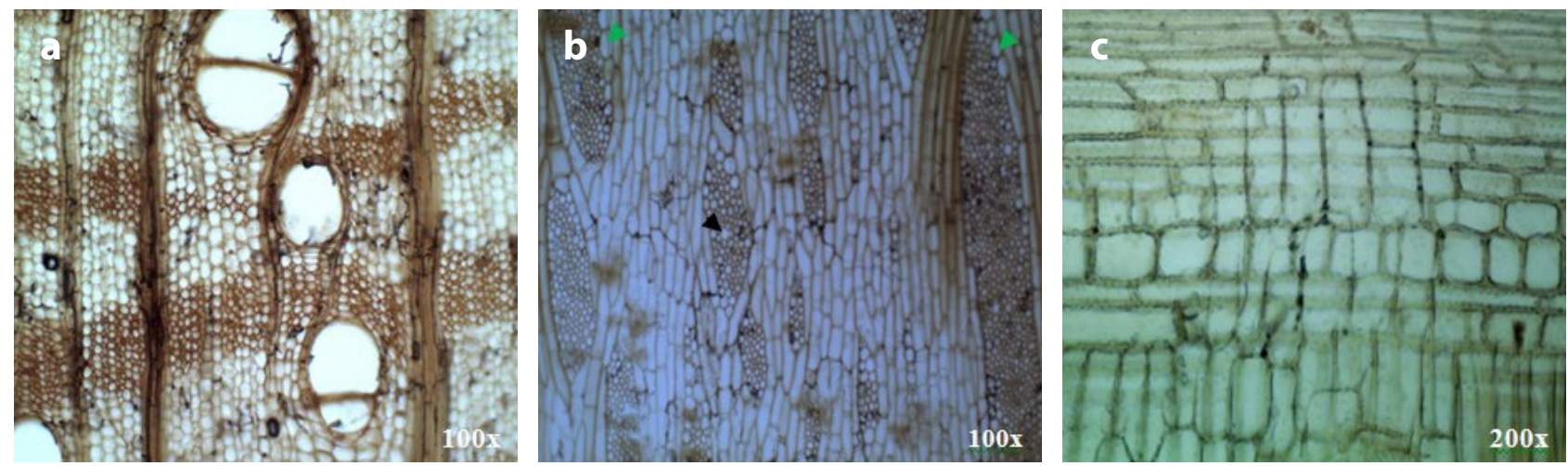

Figure 1. Microphotographs of wood sections under the microscope in transmitted light showing the anatomical characteristics of sycamore fig: $a$ ) transverse section; $b$ ) tangential longitudinal section; $c$ ) radial longitudinal section.
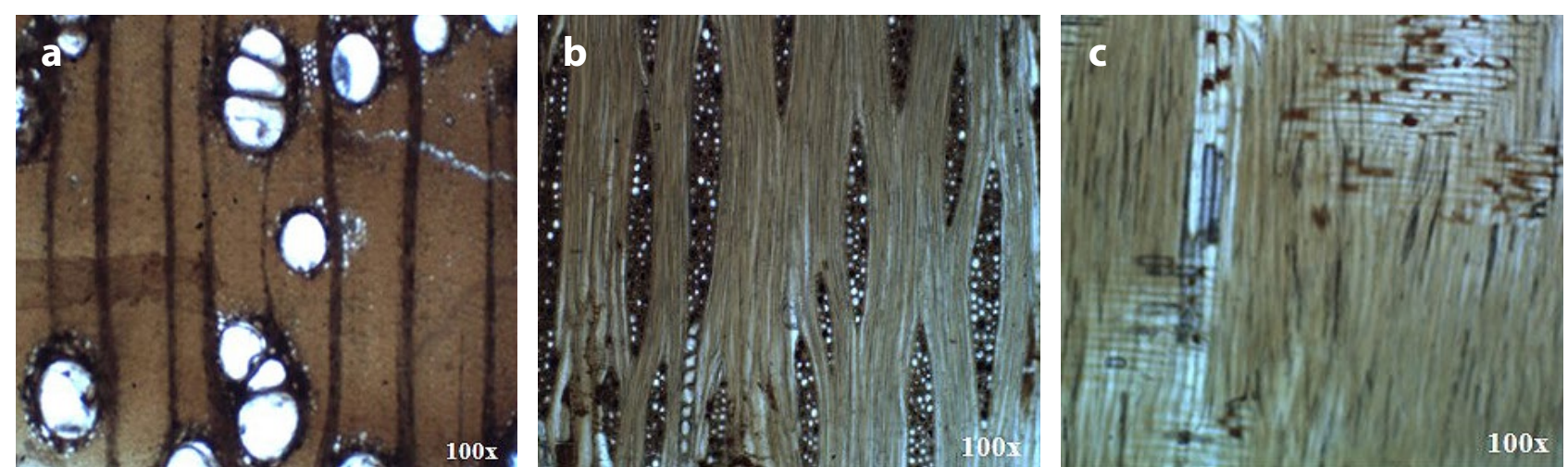

Figure 2. Microphotographs of wood sections under the microscope in transmitted light showing the anatomical characteristics of Nile acacia: $a$ ) transverse section; $b$ ) tangential longitudinal section; $c$ ) radial longitudinal section
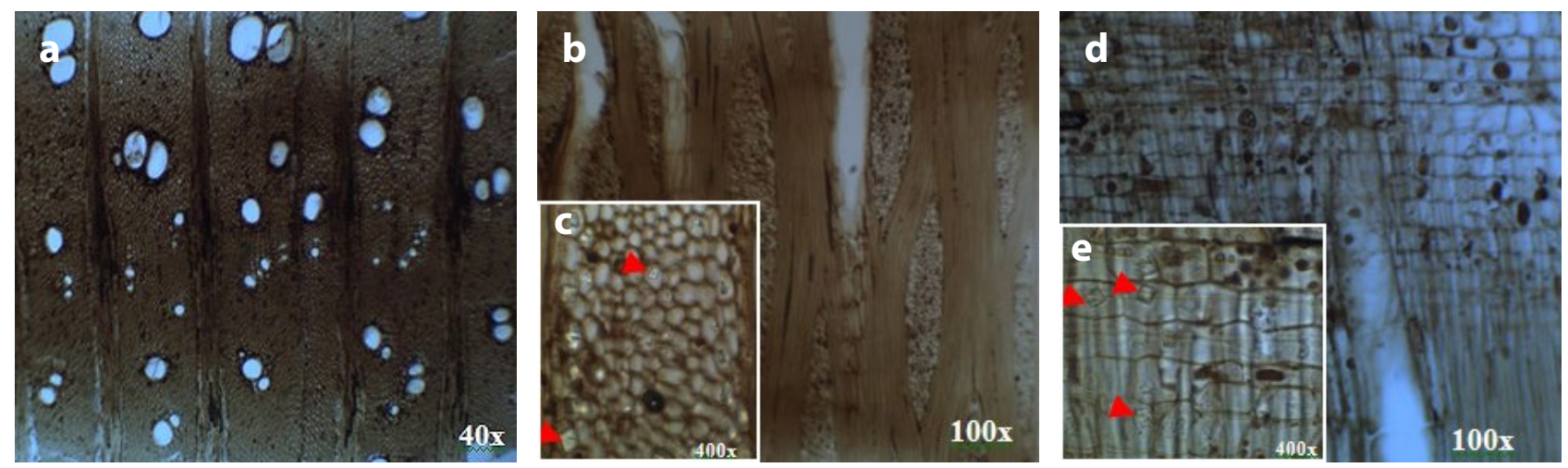

Figure 3. Microphotographs of wood sections under the microscope in transmitted light showing the anatomical characteristics of Nile tamarisk: $a$ ) transverse section; $b, c$ ) tangential longitudinal section; $d, e$ ) radial longitudinal section.

Nile tamarisk. The properties of the tamarisk wood include medium bending and compression strength, moderate hardness and a coarse and fibrous texture. Such properties made tamarisk wood a favored choice in ancient Egypt for making tenons and dowels $[1,21]$.

\section{Optical and scanning electron microscopy}

The cross-sections of the painted sampled area reveal the stratigraphic structure of the coffin (Figure 4). They also show the size and shape of the pigments' grains, as well as the materials used for the preparation, e.g. the typical grain shape of gypsum. It is obvious, apart from the black sample, that all the samples have a thin paint layer, a white, finely grained preparation layer underneath, and a coarse preparation layer at the bottom. This 3-layer structure (paint layer, fine and coarse preparation layers) can also be visualized in the SEM. The presence of a coarse preparation layer directly covering the wood was observed in previous works [1-2, 22], and was possibly used to smooth out unevenness in the joints and to suppress wood defects. 
Table 1

Characteristic anatomical features of sycamore fig, Nile acacia and Nile tamarisk used in the coffin

\begin{tabular}{|c|c|c|c|}
\hline $\begin{array}{l}\text { Anatomical } \\
\text { characteristics }\end{array}$ & $\begin{array}{l}\text { Sycamore fig } \\
\text { Ficus sycomorus }\end{array}$ & $\begin{array}{l}\text { Nile acacia } \\
\text { Acacia nilotica }\end{array}$ & $\begin{array}{l}\text { Nile tamarisk } \\
\text { Tamarix nilotica }\end{array}$ \\
\hline Growth rings & Absent & Absent & Distinct \\
\hline Vessels porosity & Diffuse & Diffuse & Ring to semi ring porous \\
\hline Vessels groupings & $\begin{array}{l}\text { In multiples of } 2 \text { to } 3(6) \text {, rarely solitary } \\
\text { (Fig. 1a) }\end{array}$ & $\begin{array}{l}\text { In multiples of } 2-3 \text {, sometimes } \\
\text { solitary } \\
\text { (Fig. 2a) }\end{array}$ & $\begin{array}{l}\text { Mostly solitary, sometimes in } \\
\text { multiples of } 2(4) \text { and clusters } \\
\text { of 3-4 } \\
\text { (Fig. 3a) }\end{array}$ \\
\hline $\begin{array}{l}\text { Parenchyma } \\
\text { arrangement }\end{array}$ & $\begin{array}{l}\text { In bands (up to } 20 \text {-cells wide), } \\
\text { scantyparatracheal or vasicentric } \\
\text { (Fig. 1a) }\end{array}$ & $\begin{array}{l}\text { Vasicentric, aliform and confluent } \\
\text { (Fig. 2a) }\end{array}$ & $\begin{array}{l}\text { Vasicentric; fusiform, } \\
\text { sometimes in 2-celled strands } \\
\text { (Fig. 3a) }\end{array}$ \\
\hline Perforation plates & Simple & Simple & Simple \\
\hline Ray seriation & $\begin{array}{l}\text { Two distinct sizes, } 1-4 \text { seriate and } 5-14 \\
\text { seriate } \\
\text { (Fig. 1b) }\end{array}$ & $\begin{array}{l}\text { 1-6 seriate } \\
\text { (Fig. } 2 b \text { ) }\end{array}$ & $\begin{array}{l}\text { (3) } 6-12 \text { seriate } \\
\text { (Fig. } 3 b \text { ) }\end{array}$ \\
\hline Ray composition & $\begin{array}{l}\text { Heterocellular composed of } \\
\text { procumbent with } 1 \text { to } 4 \text { rows of upright } \\
\text { and square marginal cells } \\
\text { (Fig. Ic) }\end{array}$ & $\begin{array}{l}\text { Homocellular composed of } \\
\text { strongly procumbent cells } \\
\text { (Fig. 2c) }\end{array}$ & $\begin{array}{l}\text { Weakly heterocellular, } \\
\text { composed of procumbent central } \\
\text { cells and square marginal cells } \\
\text { (Fig. 3d) }\end{array}$ \\
\hline Crystals & $\begin{array}{l}\text { Solitary, prismatic, in ordinary ray and } \\
\text { parenchyma cells } \\
\text { (Fig. 1c) }\end{array}$ & $\begin{array}{l}\text { Solitary, prismatic in chambered } \\
\text { parenchyma cells }\end{array}$ & $\begin{array}{l}\text { Prismatic in ray cells } \\
\text { (Fig. 3d and 3e, red arrow } \\
\text { heads) }\end{array}$ \\
\hline Laticifers & $\begin{array}{l}\text { Observed in rays } \\
\text { (Fig. 1b, black arrow head) }\end{array}$ & Absent & Absent \\
\hline Sheath cells & $\begin{array}{l}\text { Present } \\
\text { (Fig. 1b, green arrow head) }\end{array}$ & Absent & Absent \\
\hline
\end{tabular}

The cross-section of the light red paint layer in Figures $4 \mathrm{a}$ and $4 \mathrm{~b}$ shows that the paint layer has a thickness of around $54 \mu \mathrm{m}$, while the fine preparation is approximately $700 \mu \mathrm{m}$ thick. The cross-section of the red paint layer in Figures $4 \mathrm{c}$ and $4 \mathrm{~d}$ shows that the paint layer has a thickness of around $15 \mu \mathrm{m}$, while the fine preparation is approximately $700 \mu \mathrm{m}$ thick and the coarse preparation layer is approximately $1 \mathrm{~mm}$ thick. The cross-section of the blue paint layer in Figure $4 \mathrm{e}$ and $4 \mathrm{f}$ shows a paint layer in the form of a relatively thick single layer, of around $65 \mu \mathrm{m}$ in thickness, while the fine preparation is approximately $628 \mu \mathrm{m}$. The cross-section of the black paint layer in Figures $4 \mathrm{~g}$ and $4 \mathrm{~h}$ shows a single layer with a thickness of around $30 \mu \mathrm{m}$, while the fine preparation is approximately $576 \mu \mathrm{m}$ thick.

\section{Technical photography}

TP for conservators offers the promise of providing a non-destructive tool for the identification of painting materials and conservation materials, and determining their spatial distribution in an artwork [23], and is becoming popular in this field because it is simple, affordable, lightweight and small [24]. For example, UVinduced luminescence imaging can reveal the distribution of luminescent materials, which include many modern conservation materials and a number of organic substances used in antiquity [13, 25-26]. In Figures 5c and 6b, many areas show white/blue patches on the surface from a quite luminescent material. This luminescence presumably relates to previous restoration materials used in the consolidation of the painted surfaces, and its presence is much more extensive than was discernible with the naked eye. Also, in Figure 6b, UV-induced luminescence revealed the presence of a yellowish emission from luminescent material on the surface. This luminescence presumably relates to natural resins and waxes used in the previous restoration interventions, or to the surviving yellow painted areas made of orpiment, since it gives yellow fluorescent properties. Moreover, in Figure 6b, areas of red pigment appeared darker when exposed to $\mathrm{UV}$ radiation. This may suggest that the red pigment is red ochre (colored by hematite, $\mathrm{Fe}_{2} \mathrm{O}_{3}$ ), consistent with the strong quenching properties of iron-based pigments [16].

Visible-induced infrared luminescence (also often called near-infrared luminescence imaging) has been developed at the British Museum and at the Courtauld Institute of Art, London, as a new imaging technique for the identification and characterization of the spatial distribution of Egyptian blue, even in amounts too small to be observed with the naked eye [27]. When this pigment is excited in the blue, green or red range of the 

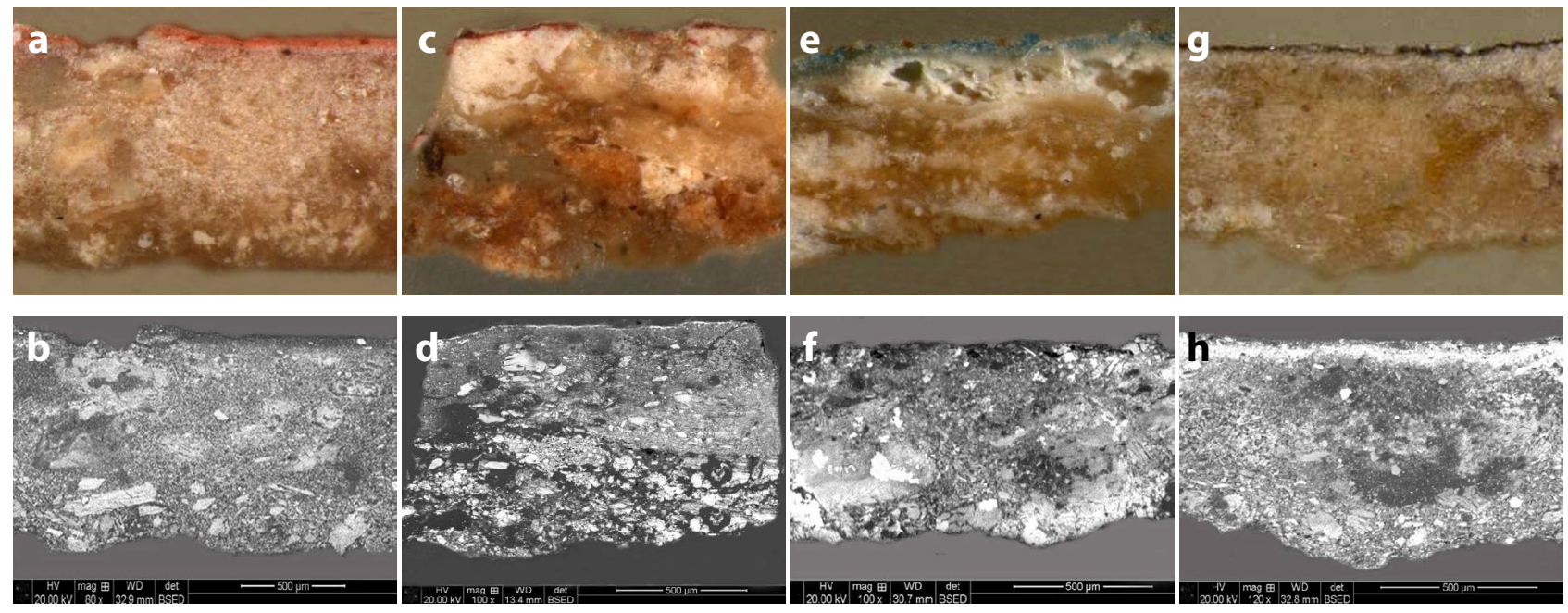

Figure 4. Optical and backscattered SEM micrographs showing the stratigraphic structure of the painted layers: $a, b)$ orange paint layer; $c, d$ ) red paint layer; $e, f$ ) blue paint layer; $g, h$ ) black paint layer.

electromagnetic spectrum, it shows an intense and broad emission in the IR range, centered at about $910 \mathrm{~nm}[28-$ 29]. This emission from Egyptian blue appears as white or very pale areas in the VIL image, while all other materials appear black or dark grey [30]. In this case, the visibleinduced infrared luminescence images (Figures $6 \mathrm{c}$ and 6d) showed that the blue and green pigments appeared as bright white, while all other materials appear dark. The luminescence of such areas could indicate the presence of Egyptian blue. In addition, infrared false color image
(Figures 5f and 6f) indicated that the areas painted with blue pigment appeared red, which confirms the presence of Egyptian blue. Moreover, comparing the visible (Figures $5 \mathrm{~b}$ and $6 \mathrm{a}$ ) and VIL images (Figures 5d and 6d) allowed for the surviving Egyptian blue pigment to be mapped and it is clear that its presence is much more extensive than was discernible with the naked eye, particularly in the green painted layer. Also, in Figure 6d scattered particles of Egyptian blue are observed elsewhere, on the surface of other painted layers. The presence of a little stray infrared
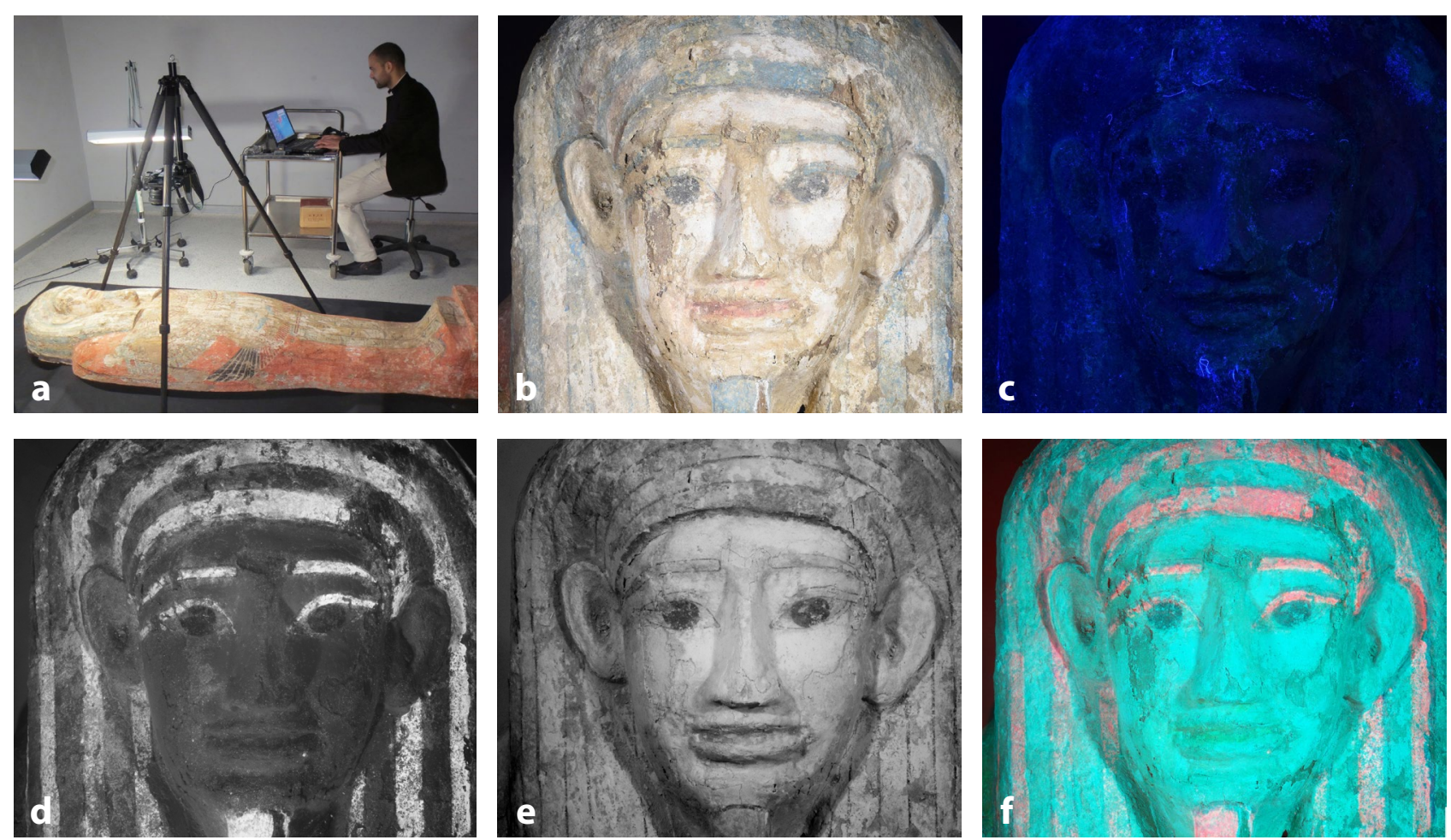

Figure 5. Technical images for the face area of the coffin made by different methods: $a$ ) set up for data capture; $b$ ) visible; $c$ ) UVinduced luminescence image; $d$ ) visible-induced luminescence image with a mixture of radiation from LED and fluorescent lamps; $e$ ) infrared; $f$ ) infrared false color. 

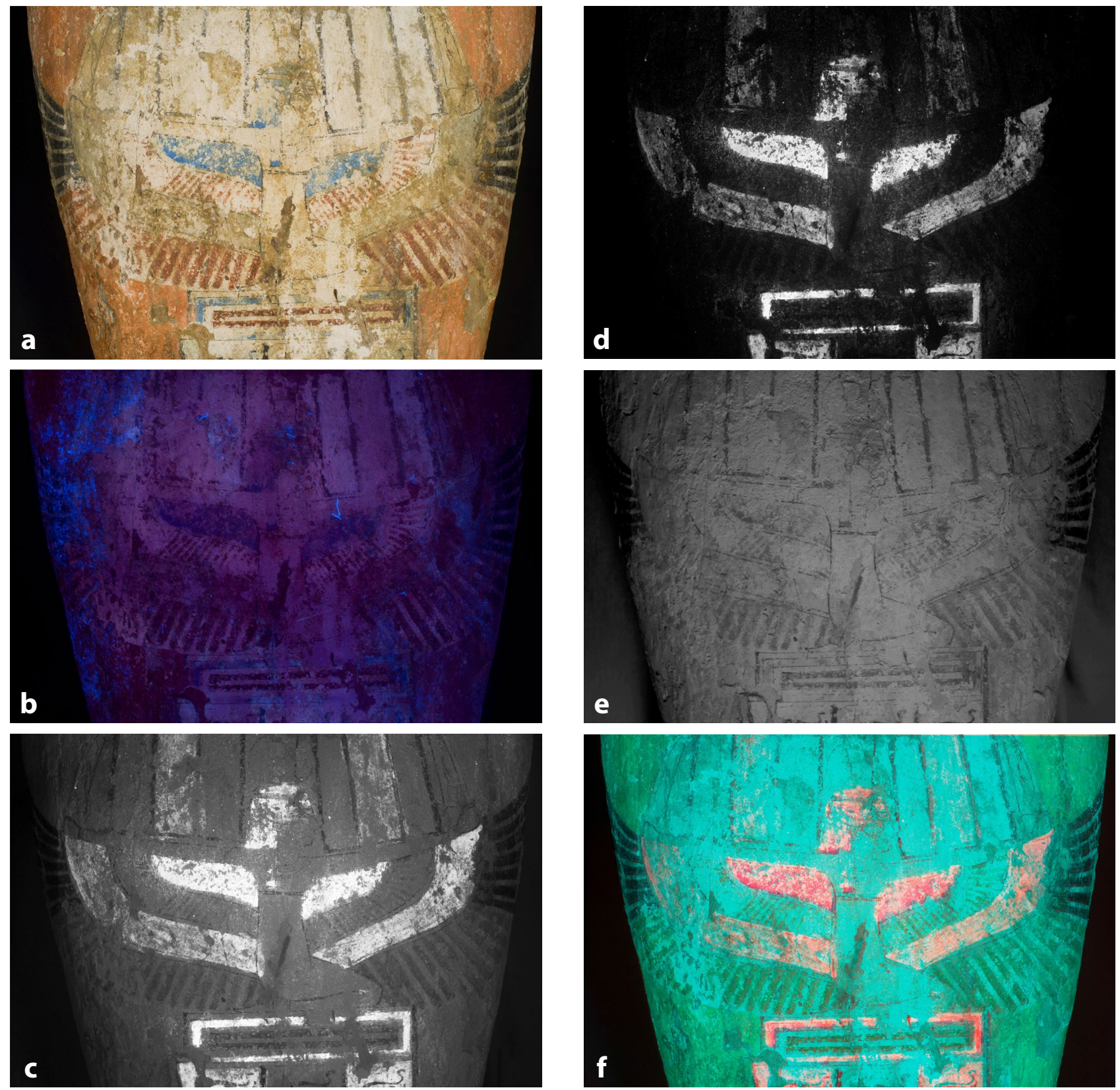

Figure 6. Technical images for the middle area of the coffin made by different methods: $a$ ) visible; $b$ ) UV-induced luminescence; $c$ ) visible-induced luminescence with a mixture of radiation from LED and fluorescent lamps; $d$ ) visible-induced luminescence with radiation from LED lamps; $e$ ) infrared; $f$ ) infrared false color.

radiation in Figure 6c makes it possible to see with great precision where within the representation of goddess Nut the surviving Egyptian blue is located. Infrared imaging is most frequently used in museums to reveal the presence of any preparatory drawings or carbon-based pigments $[25$, 31]. Carbon is particularly opaque under IR, making this technique useful for mapping the distribution of carbonbased pigments [32]. In this case, by employing infrared imaging (Figures 5e and 6e), it is possible to reveal black outlines, which did not clearly appear in the visible light due to the negative impacts of the previous treatments. Moreover, a carbon-based black pigment is supported by the false color image (Figure 6f), where the black lines appeared black. In infrared false color images, carbonbased pigment appears black as it absorbs in both the visible and infrared ranges [16].

\section{XRF, FTIR and XRD analysis}

Table 2 summarizes the XRF analysis results for the different painted preparation layers. All the XRF spectra, acquired on the surface of the coffin, showed the peaks of calcium and sulfur, related to the gypsum $\left(\mathrm{CaSO}_{4} \cdot 2 \mathrm{H}_{2} \mathrm{O}\right)$ in the preparation layer. Iron, copper, titanium, and strontium signals were also observed. These elements can be found as common impurities in rocks used to prepare ground layers. 
Table 2

XRF analysis results

\begin{tabular}{|c|c|}
\hline Color & XRF \\
\hline $\begin{array}{l}\text { White fine } \\
\text { preparation layer }\end{array}$ & $\mathbf{S}, \mathbf{C a}, \mathbf{C l}, \mathrm{As}, \mathrm{Fe}, \mathrm{Cu}, \mathrm{Ti}, \mathrm{Sr}$ \\
\hline $\begin{array}{l}\text { Creamy coarse } \\
\text { preparation layer }\end{array}$ & $\mathbf{C a}, \mathbf{S i}, \mathbf{C l}, \mathrm{Al}, \mathrm{Fe}, \mathrm{S}, \mathrm{As}, \mathrm{K}, \mathrm{Cu}, \mathrm{Ti}, \mathrm{Sr}$ \\
\hline Light red & $\mathbf{S}, \mathbf{C a}, \mathbf{F e}, \mathbf{S i}, \mathbf{C l}, \mathrm{K}, \mathrm{Cu}, \mathrm{Ti}, \mathrm{Sr}$ \\
\hline Red & $\mathbf{C a}, \mathbf{S}, \mathbf{S i}, \mathbf{F e}, \mathbf{C l}, \mathrm{Al}, \mathrm{K}, \mathrm{As}, \mathrm{Cu}, \mathrm{Ti}, \mathrm{Sr}$ \\
\hline Yellow & $\mathbf{S}, \mathbf{C a}, \mathrm{As}, \mathrm{Si}, \mathrm{Cl}, \mathrm{Fe}, \mathrm{K}, \mathrm{Cu}, \mathrm{Ti}, \mathrm{Sr}$ \\
\hline Blue & $\mathbf{S i}, \mathbf{C u}, \mathbf{C a}, \mathbf{C l}, \mathbf{S}, \mathrm{Fe}, \mathrm{K}, \mathrm{As}, \mathrm{Ti}, \mathrm{Sr}$ \\
\hline Green & $\mathrm{Ca}, \mathrm{Si}, \mathbf{S}, \mathbf{C l}, \mathbf{C u}, \mathrm{Al}, \mathbf{F e}, \mathrm{K}, \mathrm{As}, \mathrm{Ti}, \mathrm{Sr}$ \\
\hline Black & $\mathbf{C a}, \mathbf{S}, \mathbf{S i}, \mathbf{C l}, \mathrm{Al}, \mathrm{Fe}, \mathrm{K}, \mathrm{Ti}, \mathrm{Cu}, \mathrm{Sr}$ \\
\hline
\end{tabular}

Elements in boldface are correlated to the main pigment mineral

In several areas, a high intensity of chlorine was found. This is indicative of the existence of halite $(\mathrm{NaCl})$. Also, traces of arsenic (As) were found in some areas, which could be related to the use of orpiment $\left(\mathrm{As}_{2} \mathrm{~S}_{3}\right)$, a yellow pigment, in other painted portions of the coffin.

\section{The preparatory layer}

In Figure 7a, the XRF spectrum of the fine preparation layer showed the presence of calcium, sulfur and chlorine. Traces of iron, arsenic and titanium were also detected.
These elements suggest that the preparation layer is calcium sulfate. In the infrared spectrum of the fine preparation layer (Figure 8a), calcium sulfate was detected (bands at 3547, 3402, 3245, 1685, 1620, c. 1157, 673 and $599 \mathrm{~cm}^{-1}$ ). Finally, applying XRD (Figure 9a) confirmed that the fine preparation layer was composed of gypsum. Anhydrite was also detected. The presence of anhydrite indicated that the preparation materials were subjected to elevated temperatures, since gypsum (dihydrate phase, $\left.\mathrm{CaSO}_{4} \cdot 2 \mathrm{H}_{2} \mathrm{O}\right)$ converts into the metastable phase bassanite (hemihydrate, $\mathrm{CaSO}_{4} \cdot 0.5 \mathrm{H}_{2} \mathrm{O}$ ) at around $90{ }^{\circ} \mathrm{C}$, while heating to above $200{ }^{\circ} \mathrm{C}$ produces the stable phase anhydrite $\mathrm{CaSO}_{4}$ [33]. In Figure 9a, we can also detect quartz, which belongs to sand deposits adhered to the surface of the preparation and painted layers.

In Figure $7 \mathrm{~b}$, the XRF spectrum of the coarse preparation layer showed the presence of calcium, silicon, and chlorine. Traces of aluminum, iron and titanium were also detected. The absence of the $\mathrm{S}$ element suggested the possibility of calcium carbonate having been used. The presence of the Si element suggested that quartz might have been used. In the infrared spectrum (Figure 8b), we can identify calcium carbonate (bands at 1450, 870 and $712 \mathrm{~cm}^{-1}$ ), and quartz (bands at 1087, 1053, 798 and 779 $\mathrm{cm}^{-1}$ ). Finally, applying XRD confirmed the presence of calcite and quartz, according to the attribution made in the XRF and FTIR spectrum.

\section{Light red pigment}

In Figure 7c, the XRF spectrum of the light red sample is shown. Apart from calcium, sulfur, silicon, chlorine and
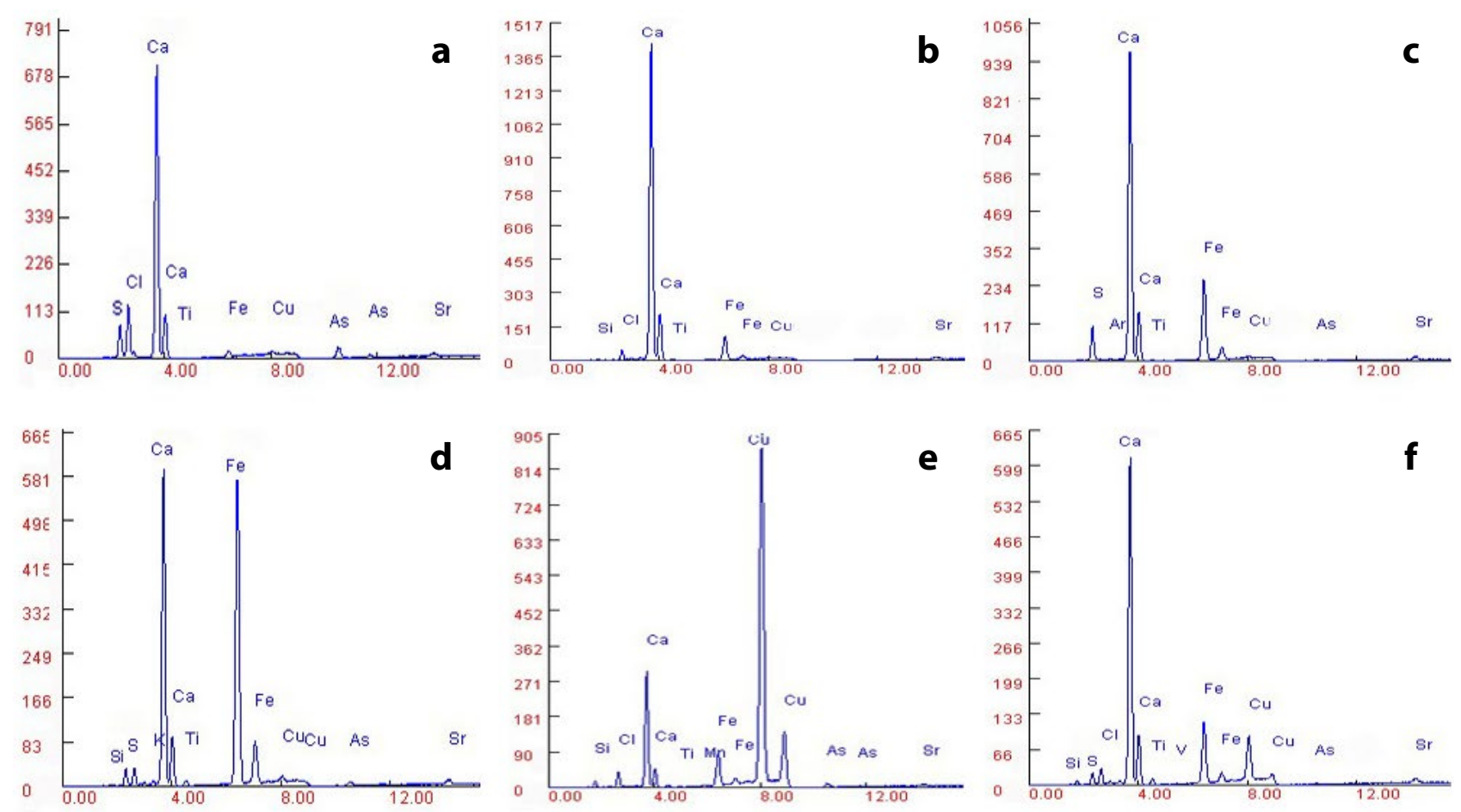

Figure 7. XRF spectra of the preparation and painted layers used on the coffin: $a$ ) fine preparation layer; $b$ ) coarse preparation layer; $c$ ) light red pigment; $d$ ) red pigment; $e$ ) blue pigment; $f$ ) green pigment. 

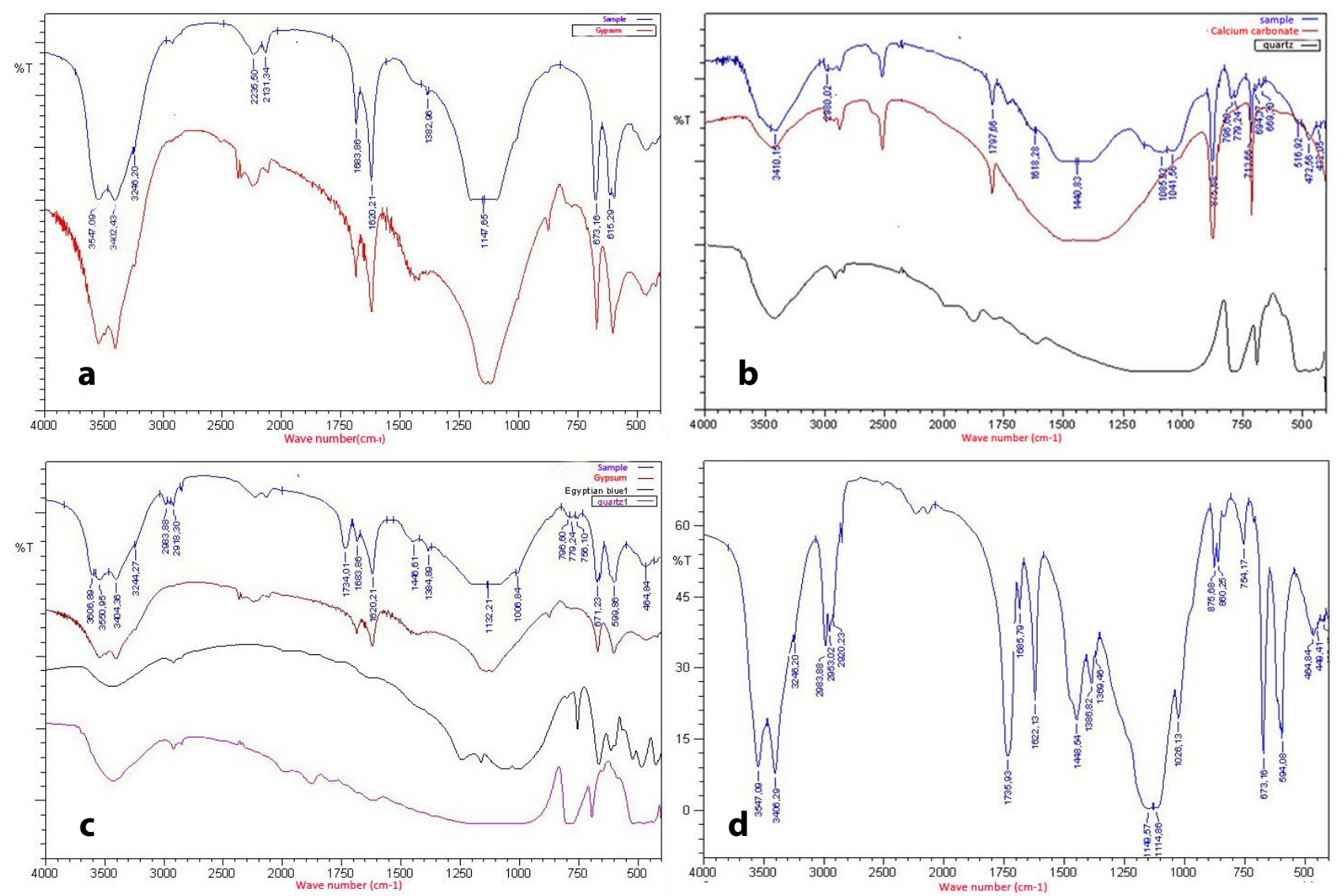

Figure 8. FTIR spectra from: $a$ ) fine preparation layer; $b$ ) coarse preparation layer; $c$ ) blue pigment; $d$ ) previous consolidation material.

potassium, iron was also detected. The presence of the Fe element suggests that red iron oxides were used to make the light red color. Applying XRD (Figure 9c) showed that, apart from gypsum, anhydrite, quartz and halite, iron oxides in hematite form are present. This last compound is considered as the pigment that defines the sample color and was very common in ancient Egypt [34].

\section{Red pigment}

The UV-induced luminescence image indicated that the red color was possibly due to red ochre (containing hematite). In Figure $7 d$, the XRF spectrum of the red sample is shown. Apart from calcium, sulfur, silicon and potassium, a high concentration of iron was also detected. In the infrared spectrum of the red sample, we can identify calcium sulfate (bands at 3547, 3402, 3245, 1685, 1620, c. 1157, 673 and $599 \mathrm{~cm}^{-1}$ ), quartz (bands at $1087,1053,798$ and $779 \mathrm{~cm}^{-1}$ ), and iron oxide in the hematite form (bands at 642 and $534 \mathrm{~cm}^{-1}$ ). Finally, applying XRD (Figure 9c) shows that, apart from gypsum, anhydrite and quartz, the presence of hematite is detected, in accordance with the attribution made in the XRF and FTIR spectra. Iron oxides in hematite form to create red color on the coffins have been reported in many works [1, 3, 35-36].

\section{Yellow pigment}

UV-induced luminescence suggested presence of remaining yellow paint areas made of orpiment pigment in the yellowish emission on the surface. The result of XRF analysis for these areas showed a high intensity of sulfur and arsenic. This result provides strong evidence for the presence of an arsenic sulfide pigment that is most likely orpiment, confirming that the yellowish emission on the surface in Figure $5 \mathrm{~b}$ is related to the surviving yellow painted areas. Orpiment $\left(\mathrm{As}_{2} \mathrm{~S}_{3}\right)$ is one of the most known arsenic sulfides and has been reported in many works for creating yellow color on (Egyptian) coffins [2, 6, 37].

\section{Blue pigment}

The VIL images strongly suggested the presence of Egyptian blue in the blue paint areas. In Figure 7, the XRF spectrum of the blue sample is shown. It shows the presence of copper, calcium, sulfur and silicon, characteristic elements of the Egyptian blue pigment. In Figure 8c, the FTIR spectrum of the blue sample is shown. This spectrum is compared with the other ones shown, of gypsum, quartz and the synthesized pigment Egyptian blue. Besides the gypsum and quartz characteristic bands, a group of bands centered at 1150, 1116, 1055 


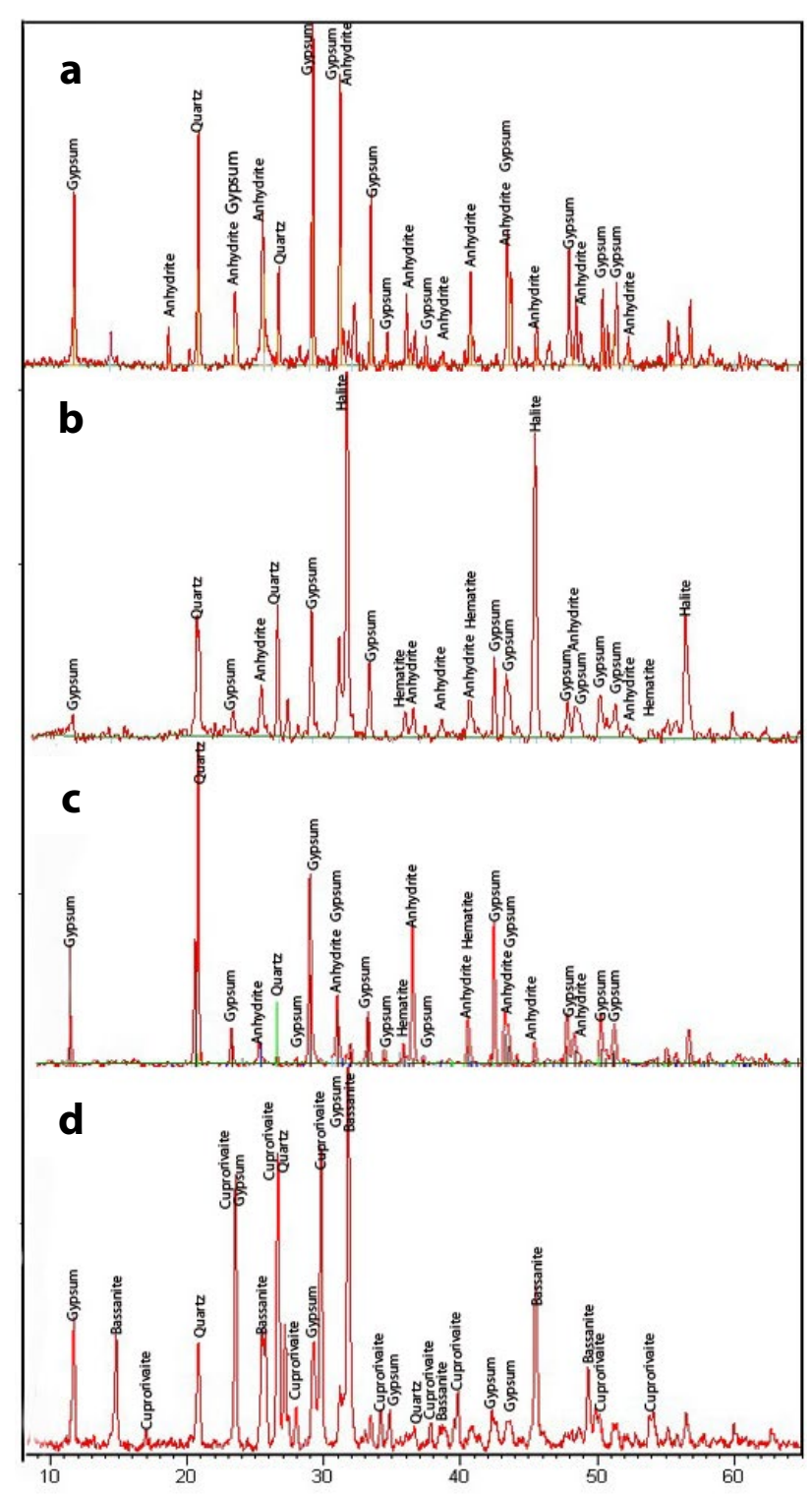

Figure 9. XRD patterns of the preparation and painted layers: $a$ ) fine preparation layer; $b$ ) light red pigment; $c$ ) red pigment; $d$ ) blue pigment.

and $1010 \mathrm{~cm}^{-1}$ is observed, attributable to Egyptian blue. Finally, applying XRD (Figure 9d) shows that, apart from gypsum and quartz, the presence of Egyptian blue is detected, in accordance with the attribution made after the XRF and FTIR spectra. No evidence was found for the presence of impurities of tin or lead in the XRF analysis, allowing us to assume that bronze scrap was not used to produce the pigment. The first documented appearance of Egyptian blue dates to the proto dynastic period in Egypt (around 3200-3000 BC), identified on a proto dynastic period bowl with markings attributed to the Scorpion King [38]. This pigment was the first synthetic pigment ever produced by humankind and was extensively used from the Fourth Dynasty in Egypt until the end of the Roman period [39]. It is a crystalline compound whose composition corresponds to a calcium copper tetrasilicate, $\left(\mathrm{CaCuSi}_{4} \mathrm{O}_{10}\right)$, which is often referred to as cuprorivaite
[40]. It is made by heating, to $c .850^{\circ} \mathrm{C}$, a mixture of a calcium compound (such as powdered limestone), a copper compound (copper ores or bronze scraps), silica (in the form of quartz sand) and a soda flux (natural sodanatron from lower Egypt, or plant ash) [41-43].

\section{Green pigment}

The VIL images strongly suggested the presence of Egyptian blue in the green paint areas. This gave strong evidence that a mixture of Egyptian blue and a yellow pigment was used to obtain the green hue. The XRF spectrum of the green sample (Figure 7f) is shown. In it, the presence of calcium, silicon, sulfur, aluminum, copper, and iron is observed. These elements provide the possibility for the presence of Egyptian blue and yellow ochre pigment. Mixtures of Egyptian blue and yellow ochre to create a green color have been reported in some works [33, 44-45].

\section{Black pigment}

IR images strongly suggested the presence of a carbonbased black in the black paint areas. The microscopic investigation of the black pigment indicated the fineness and evenness of the particles and did not show any fibrous structure, so it is possible to exclude a burnt vegetable origin for the black pigment. In the XRF spectrum, phosphorus was not detected, so it was possible to exclude an animal origin for the black pigment. The bands that define the FTIR spectrum of the black sample permitted calcium sulfate compounds (bands at 3547, 3402, 3245, 1685,1620 , c. 1157,673 and $599 \mathrm{~cm}^{-1}$ ) to be detected. No band associated with any organic or inorganic pigment was detected in the FTIR spectrum. Because graphite and amorphous carbon cannot be detected by FTIR, we have studied the sample by XRD. With it, the presence of gypsum and quartz was confirmed, and we could also detect carbon, a result which has also been reported by many authors $[3,4,46]$.

\section{Previous consolidation material}

In accordance to the previous interventions records, the FTIR analysis of previous consolidation material confirmed the presence of Primal AC 33 (bands at 2983, 2953, 1735, 1448, 1286, 1149, 1026, 860 and $754 \mathrm{~cm}^{-1}$, Figure 8d), a synthetic acrylic dispersion that slowly increased in popularity during the 1950 s, and was used as surface treatment for wall paintings and also for other materials [47]. In the spectrum of Figure 8d, calcium sulfate (bands at $3547,3402,3245,1685,1622$, c. 1114 , 673 and $594 \mathrm{~cm}^{-1}$ ) and quartz (bands at 1027 and 798 $\mathrm{cm}^{-1}$ ) are also visible.

\section{Salt efflorescences}

In the XRF spectrum of the salt sample, a high intensity of chlorine was detected, which is indicative 
of the existence of sodium chloride $(\mathrm{NaCl})$. By applying $\mathrm{XRD}$, halite $(\mathrm{NaCl})$ was confirmed. Salt crystallization in porous materials constitutes one of the most frequent causes of decay and aggressive deterioration problems [48], which occur on wood surfaces, plasters and renderings through saline solutions transferred to the (in this case wood) pores. These salts can be observed directly as efflorescences, which appear and disappear periodically according to the presence or absence of moisture sources [49]. Pressures created by salt crystallization in pores weaken the material until its mechanical strength is overcome and damage occurs [50], which can be defined as a consequence of repeated dissolution and crystallization processes. The forms of salt crystallization on painted wooden artifacts are the most important chemical reaction involving salinity ground water to cause degradation phenomena. When these salts are formed on a porous wood, they cause several aspects of deterioration including weakening of wood cells, deformation of wood surface and disintegration of plaster and decorated layers, besides obscuring the original surface.

\section{Conclusion}

In this study, by applying a combination of OM, TP, XRF, XRD and FTIR spectroscopy, the identification of wood species and the chemical compositions of the materials used in the preparatory and pictorial paint layers from the coffin GEM 10831 were successfully identified. The identification of wood species indicated that the ancient Egyptian carpenter made the planks of the coffin with a native wood sycamore fig not strong enough, but in case of the dowels and tenon where load stresses occurred, denser and stronger wood species (Nile acacia and Nile tamarisk, respectively) were used. Two preparation layers were observed on the wood surface through via micro-stratigraphic analysis. The fine preparation layer was proved to be made of pure gypsum, while the coarse preparation layer was based on a mixture of calcite and quartz. The chromatic palette used in the coffin was identified as Egyptian blue (cuprorivaite), red ochre (hematite), orpiment and carbon black. The green pigment was obtained through a mixture of Egyptian blue and yellow ochre. Salts were identified as a sodium chloride. Primal AC 33 was confirmed as the consolidation material applied in a previous intervention treatment. The application of TP provided useful information about the spatial distribution of the surviving original pigments and the materials used in the previous restoration interventions, in particularly VIL, which played an important role in recognizing the spatial distribution of areas containing Egyptian blue, even in trace amounts or mixed with other pigments, such as yellow. However, complete characterization of the pigments required the use of other techniques, such as XRF, XRD and FTIR spectroscopy. As a result, numerous analytical techniques have found a valuable application in the identification of pigments. However, every single method has particular limitations. For this reason, in most cases it is necessary to employ a combination of several techniques in order to obtain a complete overview of the composition of a layer of paint.

\section{Acknowledgments}

The authors would like to thank the staff of GEM-CC, Mohamed Anwar (SEM), Dina Mamdouh (FTIR), Hssan Zidan (XRD) and Ngm Eldin Morshed (XRF), for assisting. The authors are much grateful to Mr. Tamer Elnwagy, supervisor of the heavy artefacts department at GEM. The authors would like to thank Dr. Osama Abo El Kheir, the General Director of Conservation Affairs, and Dr. Tarek Tawfik, General Director, at GEM. We would like to express our gratitude to the Japan International Cooperation Agency (JICA) for its continuous technical and financial support.

\section{References}

1 Abdrabou, A.; Abdallah, M.; Abd El Kader, M., 'Analytical study and conservation processes of a painted wooden Graeco-Roman coffin', International Journal of Conservation Science 6(4) (2015) 573-586, http://www.ijcs. uaic.ro/public/IJCS-15-40_Abdrabou.pdf (accessed 201705-05).

2 Abd El-Tawab Bader, N. A.; Al-Gharib, W. K., 'Assessment of deterioration and conservation of a polychrome wooden coffin, from al-Arish museum, Egypt', International Journal of Conservation Science 4(4) (2013) 397-412, http://www. ijcs.uaic.ro/public/IJCS-13-38-Bader.pdf (accessed 201705-05).

3 Afifi, H.; AbdEl Fatah, M. A., 'Analytical study of ground painting layers and conservation processes of an Egyptian painted coffin', Journal of Life Sciences 5 (2011) 661-669.

4 Johnson, C.; Head, K.; Green, L., 'The conservation of a polychrome Egyptian coffin', Studies in Conservation 40 (1995) 75-82, https://doi.org/10.1179/sic.1995.40.2.73.

5 Proietti, N.; Presciutti, F.; Di Tullio, V.; Doherty, B.; Marinelli, A.; Provinciali, B.; Macchioni, N.; Capitani, D.; Miliani, C., 'Unilateral NMR, 13C CPMAS NMR spectroscopy and micro-analytical techniques for studying the materials and state of conservation of an ancient Egyptian wooden sarcophagus', Analytical and Bioanalytical Chemistry 399(9) (2011) 3117-3131, https://doi.org/10.1007/s00216010-4229-z.

6 Amenta, A. 'The Vatican Coffin project', in Thebes in the First Millennium, ed. E. Pischikova. J. Budka \& K. Griffen, Cambridge Scholars Publishing, Cambridge (2014) 483- 99.

7 Bracci, S.; Caruso, O.; Galeotti, M.; Iannaccone, R.; Magrini, D.; Picchi, D.; Pinna, D.; Porcinai, S., 'Multidisciplinary approach for the study of an Egyptian coffin (late 22nd/ early 25th dynasty): Combining imaging and spectroscopic techniques', Spectrochimica Acta Part A: Molecular and Biomolecular Spectroscopy 145 (2015) 511-522, https://doi. org/10.1016/j.saa.2015.02.052.

8 IAWA Committee, List of microscopic features for softwood identification, IAWA Journal 25 (2004) 1-70, https://doi. org/10.1163/22941932-90000349.

9 Crivellaro, A.; Schweingruber, F. H., Atlas of Wood, Bark and Pith Anatomy of Eastern Mediterranean Trees and Shrubs with Special Focus on Cyprus, Springer-Verlag, Berlin (2013).

10 'Acacia nilotica', in The Inside Wood Database, http://insidewood.lib.ncsu.edu (accessed 2016-06-17). 
11 'Tamarix nilotica', in The Inside Wood Database, http://insidewood.lib.ncsu.edu (accessed 2016-06-17).

12 Cosentino, A., 'Identification of pigments by multispectral imaging; a flowchart method', Heritage Science 2 (2014) 8 https://doi.org/10.1186/2050-7445-2-8.

13 Cosentino, A., 'Practical notes on ultraviolet technical photography for art examination', Conservar Património 21(2015) 53-62, https://doi.org/10.14568/cp2015006.

14 Verri, G.; Saunders, D.; Ambers, J.; Sweek, T., 'Digital mapping of Egyptian blue: Conservation implications', Studies in Conservation 55(Sup2) (2010) 220-224, http:// dx.doi.org/10.1179/sic.2010.55.Supplement-2.220.

15 Dyer, J.; Verri, G.; Cupitt, J., Multispectral Imaging in Reflectance and Photo-induced Luminescence Modes: A User Manual, The British Museum, London (2013), www. britishmuseum.org/pdf/charisma-multispectral-imaging-manual-2013.pdf (accessed 2017-05-05).

16 Dyer, J.; O'Connell, E. R.; Simpson, A., 'Polychromy in Roman Egypt: a study of a limestone sculpture of the Egyptian god Horus', The British Museum Technical Research Bulletin 8 (2014) 93-103, http://www.britishmuseum.org/pdf/BMTRB_8_Dyer_OConnell_and_Simpson.pdf (accessed 2017-05-05).

17 Cosentino, A., 'Effects of different binders on technical photography and infrared reflectography of 54 historical pigments, International Journal of Conservation Science 6(3) (2015) 287-298, http://www.ijcs.uaic.ro/public/IJCS-15-27_ Cosentino.pdf (accessed 2017-05-05).

18 Derrik, R. M.; Stulik, D.; Landy, M. J., Infrared Spectroscopy in Conservation Science, The Getty Conservation Institute, Los Angeles (1999).

19 Gale, R.; Gasson, P.; Hepper, N., 'Wood', in Ancient Egyptian Materials and Technology, ed. T. Nicholson \& I. Shaw, Cambridge University Press, Cambridge (2000) 334371.

20 Dawson, J.; Marchant, J.; Von Aderkas, E.; Cartwright, C.; Stacy, R., 'Egyptian coffins: materials, construction and decoration, in Death on the Nile (Uncovering the Afterlife of Ancient Egypt), ed. H. Strudwick \& J. Dawson, The Fitzwilliam Museum, Cambridge (2016) 75-246.

21 Cartwright, C.; Taylor, J. H., 'Wooden Egyptian archery bows in the collections of the British Museum', The British Museum Technical Research Bulletin 2 (2008) 77-83, https://www.britishmuseum.org/pdf/BMTRB\%202\%20 Cartwright\%20and\%20Taylor.pdf (accessed 2017-05-05).

22 Stein, R. A.; Lacounra, P., 'Observations on the preparation layers found on ancient Egyptian decorated coffins in the Michael C. Carlos Museum', in Decorated Surfaces on Ancient Egyptian Objects Technology, Deterioration and Conservation, ed. J. Dawson, C. Rozeik, M.M. Wright, Archetype Publications, London (2010) 3-8.

23 Delaney, J. K.; Walmsley, E.; Berrie, B. H.; Fletcher, C. F., 'Multi-spectral imaging of paintings in the infrared to detect and map blue pigments', in Scientific Examination of Art. Modern Techniques in Conservation and Analysis, National Academies Press, Washington, (2005) 120-136, https:// www.nap.edu/read/11413/chapter/10 (accessed 2017-0505).

24 Cosentino, A., 'Multispectral imaging and the art expert', Spectroscopy Europe 27(2) (2015) 6-9.

25 Grant, M. S., 'The use of ultraviolet induced visible-fluorescence in the examination of museum objects, Part II', National Park Service Conserve O Gram 1(10) (2000), https://www.nps.gov/museum/publications/conserveogram/01-10.pdf (accessed 2017-05-05).

26 Verri, G.; Gleba, M.; Swaddling, J.; Long, T.; Ambers, J.; Munden, T., 'Etruscan women's clothing and its decoration: the polychrome gypsum statue from the 'Isis Tomb' at Vulci', The British Museum Technical Research Bulletin
8 (2014) 59-71, http://www.britishmuseum.org/pdf/ BMTRB_8_Verri_et_al.pdf (accessed 2017-05-05).

27 Verri, G., 'The use and distribution of Egyptian blue: a study by visible-induced luminescence imaging in conservation', in Scientific Examination and Re-display of the Nebamun Wall Paintings, ed. K. Uprichard \& A. Middleton, Archetype Publications, London (2008) 41-50.

28 Verri, G., 'The application of visible-induced luminescence imaging to the examination of museum objects', in Proceedings of SPIE7391 - O3A: Optics for Arts, Architecture, and Archaeology II, ed. L. Pezzati \& R. Salimbeni (2009), https://doi.org/10.1117/12.827331.

29 Accorsi, G.; Verri, G.; Bolognesi, M.; Armaroli, N.; Clementi, C.; Miliani, C.; Romani, A., 'The exceptional near-infrared luminescence properties of cuprorivaite (Egyptian blue), Chemical Communications 23 (2009) 3392-3394, https://doi.org/10.1039/B902563D.

30 Verri, G.; Opper, T.; Deviese, T., 'The Treu Head: a case study in Roman sculptural polychromy', The British Museum Technical Research Bulletin 4 (2010) 39-54, https://www. britishmuseum.org/pdf/BMTRB4\%20Verri.pdf (accessed 2017-05-05).

31 Stuart, B., Analytical Techniques in Materials Conservation, John Wiley \& Sons, Ltd, Chichester (2007).

32 Passmore, E.; Ambers, J.; Higgitt, C.; Ward, C.; Wills, B.; Simpson, S. J.; Cartwright, C., 'Hidden, looted, saved: the scientific research and conservation of a group of Begram Ivories from the National Museum of Afghanistan', The British Museum Technical Research Bulletin 6 (2012) 33-46, https://www.britishmuseum.org/pdf/BMTRB_6_Passmoreet-al.pdf (accessed 2017-05-05).

33 Scott, D. A.; Warmlander, S.; Mazurek, J.; Quirke, S., 'Examination of some pigments, grounds and media from Egyptian cartonnage fragments in the Petrie Museum, University College London', Journal of Archaeological Science 36(3) (2009) 923-932, https://doi.org/10.1016/j. jas.2008.12.011.

34 MeCartby, B., 'Technical analysis of reds and yellows in the tomb of Suemniwet, Theban tomb 92', in Colour and Painting in Ancient Egypt, ed. W. V. Davies, The British Museum Press, London (2001) 17-21.

35 Abdrabou, A.; Elbaroudy,A.; Abdallah, M.; Abd El Kader, M.; Matsuda, Y., 'Analytical study and conservation processes of some ancient Egyptian wooden artifacts', poster, ICOM-CC 17th Triennial Conference, Melbourne (2014).

36 Abdelaal, S.; Mahmoud, N.; Detalle, V., 'A technical examination and the identification of the wood, pigments, grounds and binder of an ancient Egyptian sarcophagus', International Journal of Conservation Science 5 (2) (2014) 177-188, http://www.ijcs.uaic.ro/public/IJCS-14-17Abdelaal.pdf (accessed 2017-05-05).

37 Bonizzoni, L.; Bruni, S.; Guglielmi, V.; Milazzo, M.; Neri, O., 'Field and laboratory multi-technique analysis of pigments and organic painting media from an Egyptian coffin (26th dynasty)', Archaeometry 53(6) (2011) 1212-1230, https://doi.org/10.1111/j.1475-4754.2011.00592.x.

38 Ganio, M.; Salvant, J.; Williams, J.; Lee, L.; Cossairt, O.; Walton, M.,' Investigating the use of Egyptian blue in Roman Egyptian portraits and panels from Tebtunis, Egypt', Applied Physics A 121(3) (2015) 813-821, https://doi. org/10.1007/s00339-015-9424-5.

39 Pradell, T.; Salvado, N.; Hatton, G. D.; Tite, M. S., 'Physical Processes Involved in Production of the Ancient Pigment, Egyptian Blue', Journal of the American Ceramic Society 89(4) (2006) 1426-1431, https://doi.org/10.1111/j.15512916.2005.00904.x.

40 Mirti, P.; Appolonia, L.; Casoli, A.; Ferrari, R. P.; Laurenti, E.; Amisano Canesi, A.; Chiari, G., 'Spectrochemical and structural studies on a roman sample of Egyptian blue', Spectrochimica Acta Part A: Molecular and Biomolecular 
Spectroscopy 51(3) (1995) 437-446, http://dx.doi. org/10.1016/0584-8539(94)E0108-M.

41 Pages-Camagna, S.; Guichard, H., 'Egyptian colours and pigments in French collections: 30 years of physicochemical analyses on 30 objects', in Decorated Surfaces on Ancient Egyptian Objects Technology, Deterioration and Conservation, ed. J. Dawson, C. Rozeik \& M. M. Wright, Archetype Publications, London (2010) 25-31.

42 Uda, M., 'Characterization of Pigments Used in Ancient Egypt', in X-Rays for Archaeology, ed. M. Uda, G. Demortier \& I. Nakai, Springer, Dordrecht (2005) 3-26, https://doi. org/10.1007/1-4020-3581-0_1.

43 Ismail, Y.; Abdrabou, A.; Abdallah, M., 'A non-destructive analytical study and the conservation processes of Pharaoh Tutankhamun's painted boat model', International Journal of Conservation Science 7(1) (2016) 15-28, http://www.ijcs. uaic.ro/public/IJCS-16-02_Ismail.pdf (accessed 2017-05$05)$.

44 Edreira, M. C.; Feliu, M. J.; Lorenzo, C. F.; Martin, J., 'Spectroscopic study of Egyptian blue mixed with other pigments', Helvetica Chimica Acta 86 (2003) 29-49, https://doi. org/10.1002/hlca.200390017.

45 Mahmoud, H. H. M., 'Investigations by Raman microscopy, ESEM and FTIR-ATR of wall paintings from Qasr el-Ghuieta temple, Kharga Oasis, Egypt', Heritage Science 2 (2014) 18, https://doi.org/10.1186/s40494-014-0018-x.

46 Karya, H.; Bruno, L.; Godfrey, J.; March, T., 'Treatment of Dynasty 18 painted coffin, 37.47E a-e (Abbott collection 405A)', in Decorated Surfaces on Ancient Egyptian Objects Technology, Deterioration and Conservation, ed. J. Dawson, C. Rozeik, \& M. M. Wright, Archetype Publications, London (2010) 97-105.
47 Horie, V., Materials for Conservation. Organic Consolidants, Adhesives and Coatings, 2nd ed., Butterworth-Heinemann, Oxford (2010).

48 Marey, H.; Kantiranis, N.; Stratis, J., 'Salt damage on the wall paintings of the festival temple of Thutmosis III, Karnak temples complex, Upper Egypt: A case study', International Journal of Conservation Sciences 1 (3) (2010) 133-142, http://www.ijcs.uaic.ro/pub/IJCS-10-13-Mahmoud.pdf (accessed 2017-05-05).

49 Arnold, A., 'Behaviour of some soluble salts in stone deterioration', in Proceedings of 2nd International Symposium on the Deterioration of Building Stones, Athens (1976) 27-36.

50 Lubelli, B.; Van Hees, R., 'Effectiveness of crystallization inhibitors in preventing salt damage in building materials', Journal of Cultural Heritage 8(3) (2007) 223-234, https:// doi.org/10.1016/j.culher.2007.06.001.

Received: $2017-2-18$

Revised: 2017-3-29

Accepted: $2017-4-25$

Online: $2017-5-8$

This work is licensed under the Creative Commons Attribution-NonCommercial-NoDerivatives 4.0 International License.

To view a copy of this license, visit http://creativecommons.org/licenses/by-nc-nd/4.0/deed.en. 